\title{
Concept Understanding Analysis of Coloid Materials After Application of Joyful Learning Problem Based Learning
}

\author{
Muflihah Muflihah $^{1 \bowtie}$, Kasmadi Imam Supardi ${ }^{2}$, Woro Sumarni ${ }^{2}$ \\ ${ }^{1}$ Islam Plus Bina Insani Susukan Senior High School, Indonesia \\ ${ }^{2}$ Chemistry Education, Mathematics and Natural Sciences Faculty, Universitas Negeri Semarang, Indonesia
}

\begin{tabular}{|c|c|}
\hline Article Info & bstract \\
\hline $\begin{array}{l}\text { Article History : } \\
\text { Received January } 2019 \\
\text { Accepted February } 2019 \\
\text { Published December } 2020\end{array}$ & \multirow{3}{*}{$\begin{array}{l}\text { Learning without strengthening understanding of concepts can cause } \\
\text { misconceptions and learning to be less meaningful. This research aims to } \\
\text { analyze students' understanding of the concept of colloidal material. The } \\
\text { research design uses quantitative descriptive methods. The research subjects } \\
\text { were students of class XI MIPA Islamic High School Plus Bina Insani } \\
\text { Susukan } 2018 / 2019 \text { academic year. Data collection using three tier multiple } \\
\text { choice tests. The results of data analysis showed } 43 \% \text { of students understood } \\
\text { the concept, } 39 \% \text { of students experienced misconceptions and } 15 \% \text { of } \\
\text { students in the category of lack of understanding and } 3 \% \text { of students guessed } \\
\text { the answers. The highest percentage of indicators shows interpreting the data } \\
\text { and giving examples of colloidal material. This shows that most of the } \\
\text { students were able to interpret the data and set examples well. Problem-based } \\
\text { learning with a joyful learning approach is enough to help students in } \\
\text { understanding students' concepts. }\end{array}$} \\
\hline Learning & \\
\hline & \\
\hline
\end{tabular}

(C) 2020 Universitas Negeri Semarang

$凶$ correspondence:

Islam Plus Bina Insani Susukan Senior High School

p-ISSN 2252-6412

Baran, Karangasem, Ketapang, Kecamatan Susukan, Semarang,

e-ISSN 2502-4523

Jawa Tengah, Indonesia 50777

E-mail: muflihah2017@students.unnes.ac.id 


\section{INTRODUCTION}

Application of learning models that are suitable for the material and conditions of students can help the implementation of teaching and learning activities that are effective and fun for students. While the application of learning models that are less precise tends to cause students to experience misconceptions and not understand the various concepts in the colloidal system material. Students' conceptions in distinguishing colloidal systems from solutions and suspensions tend to be in the category of partial understanding with misconceptions. Students' conceptions tend to be in the category of not understanding the subconcepts of colloid making, the nature of colloids and the application of colloids in life. Whereas in the concept of the types of colloids students tend to have conceptions in the category of partial understanding or misconception. Likewise with the concept of liofil liofob colloids the tendency of students' conception is in the category of misconception (Latisma et al., 2015). Learning that tends to be teacher-centered can lead to students 'interest in learning so that students' understanding of concepts is not optimal, especially in theoretical subject matter such as colloids (Yahya et al., 2017).

One of the goals of learning chemistry in high school is that students have the ability to understand chemical concepts, principles, laws and theories as well as their interrelations and their application to solve problems in daily life and technology. Judging from the reality, it turns out that the goal has not been reached to the maximum. Students' understanding of the chemical concept appropriately will produce longlasting knowledge in their minds so that it is easy for students to recall the chemical concept if one day it is needed.

Colloid material contains concepts that are not enough to just memorize, but there are concepts that need to be observed, for example, why does coconut milk if left to stand for a while will form two layers? why before drinking cough fins should be shaken first? These concepts must be explained and can be understood in depth, so it is necessary to understand concepts that are directly related to everyday life. Colloidal system material is divided into four sub-materials, namely colloidal system, colloidal properties, colloid making and the role of colloids in daily life. Colloidal System material is divided into four submaterials, namely colloidal system, colloidal properties, colloidal manufacture and the role of colloids in daily life.

Conventional learning models do not accustom active students in the learning process, so that communication failures can occur in the delivery of material so that subject matter or messages conveyed by teachers cannot be received by students optimally, or can cause misunderstanding. To minimize the failure of communication, the teacher needs to develop a learning strategy by utilizing various learning media and learning resources.

Some learning models can be used to improve students' understanding of concepts including guided discovery (Salawati et al., 2016). The problem based learning project model can also improve students' understanding of concepts in colloidal material (Wulandari, 2015). Teams Games Tournament learning methods assisted by demonstrations show no interaction with learning achievement (Isnaniyah et al., 2015). Learning Cycle learning model has not been able to achieve the expected average value (Bilkisty et al., 2013).

Problem based learning can improve students' understanding of concepts and critical thinking (Pratama et al., 2017). PBL (Problem Based Learning) is a learning model in which students become more experienced in gathering, organizing, and storing information in a form that can be used for future use, as well as facing and solving complex complex problems that are realistic (Abanikannda, 2016). The colloidal system learning model with inquiry only helps students to master fundamental chemical concepts not yet to the application of colloids in everyday life (Soesanto, 2017). The Problem Based Learning model makes learning more meaningful according to research conducted by Dewi et al. (2013) that Problem Based Learning can improve social interaction and learning achievement in colloidal system material.

Fun learning can have a positive effect on student learning outcomes. Joyful learning is defined as a learning process or experience that can make students feel pleasure in a learning scenario / process (Wei et al., 2011). Joyful 
Learning still requires stimulant media to make students more active in learning. In addition, the media can represent what teachers are less able to say through certain words or sentences (Asmani \& Jamal, 2014). Joyful Learning with effective assignment methods for students' cognitive and affective learning achievement (Permatasari et al., 2014).

The results of research on the use of crossword puzzles on colloidal material with the results of students' responses to the crossword puzzle media provide positive responses and increase learning outcomes (Sulfia \& Habibati, 2017). In addition, the application of the Joyful Learning learning model with action card media can have a better influence on chemistry learning outcomes on colloidal material (Mushbiroh et al., 2018).

Students activities that stand out in joyful learning-based learning are students who are more enthusiastic in completing assignments given by the teacher, dare to present their work in front of the class, and many students ask questions and opinions (Triastuti et al., 2014). Joyful learningbased learning methods in learning can increase student motivation so that it has an impact on improving learning achievement.

This research aims to analyze the understanding of the concept of students on colloidal material. To achieve these objectives, the application of problem based learning is approached by joyful learning. This research is expected to contribute to the world of education in general and chemistry learning in particular.

\section{METHODS}

The study was conducted at one of the high schools in Semarang Regency using quantitative descriptive methods. The subjects of this study were students of class XI MIPA with a total of 42 students with 30 girls and 12 sons. Data collection techniques using the Three Tier Multiple choice test, where the first tier shows the answer statement, the second tier shows the reason and the third tier shows the confidence of the answer. The number of questions tested was 20 questions which included indicators of concept understanding. Data analysis techniques using percentage techniques. Guidelines for interpretation of student test results to group categories of understanding, misconception, lack of understanding and guessing based on Arslan et al. (2012) as in Table 1.

Table 1. Interpretation of Concept Understanding Tests

\begin{tabular}{|c|c|c|c|}
\hline First Tier & $\begin{array}{l}\text { Second } \\
\text { Tier }\end{array}$ & $\begin{array}{l}\text { Third } \\
\text { Tier }\end{array}$ & Category \\
\hline Correct & Correct & Certain & $\begin{array}{l}\text { Conceptual } \\
\text { understanding }\end{array}$ \\
\hline Correct & Incorrect & Certain & $\begin{array}{l}\text { Type } 1 \\
\text { misconception }\end{array}$ \\
\hline Incorrect & Correct & Certain & $\begin{array}{l}\text { Type } 2 \\
\text { misconception }\end{array}$ \\
\hline Incorrect & Incorrect & Certain & $\begin{array}{l}\text { Type } 3 \\
\text { misconception }\end{array}$ \\
\hline Correct & Incorrect & Uncertain & $\begin{array}{l}\text { Type } 1 \text { lack of } \\
\text { understanding }\end{array}$ \\
\hline Incorrect & Correct & Uncertain & $\begin{array}{l}\text { Type } 2 \text { lack of } \\
\text { understanding }\end{array}$ \\
\hline Incorrect & Incorrect & Uncertain & $\begin{array}{l}\text { Type } 3 \text { lack of } \\
\text { understanding }\end{array}$ \\
\hline Correct & Correct & Uncertain & Guess \\
\hline
\end{tabular}

Based on the table, students are in the category of understanding concepts if they are able to answer questions correctly and can state the reasons correctly and have confidence in the answers. The category 1 type of misconception if students are able to answer correctly, but the reasons given are not right and have confidence in the answers given.

Students with the type 2 misconception category if they give incorrect answers, the reasons given are correct and have confidence in the answers. The type 3 misconception category is for students who give incorrect answers and reasons but have confidence in the answers given. The next category is not understanding the concept. Students who do not have confidence in the answers given are in this category.

Categories do not understand the concept of type 1 if students give the right answer but the reasons given are not right and do not have confidence in the answers given. Meanwhile, if students give incorrect answers but the right reasons and are not sure of the answers given fall into the category of lack of understanding of type 2 concepts. Categories lack understanding of type 3 if students give incorrect answers and reasons 
and do not have confidence in the answers which is given. If the students give the right answers and reasons but do not have confidence in the answers given, the students belong to the guessing category.

\section{RESULTS AND DISCUSSION}

After learning with the Problem based learning model approached Joyful learning and post test, the results of students' answers are further grouped into 8 categories based on Arslan et al. (2012) namely, (1) conceptual understanding, (2) type 1 misconception, (3) type 2 misconception, (4) type 3 misconception, (5) type 1 lack of understanding, (6) type 2 lack understanding, (7) ) lack of understanding of type 3 and (8) guess. The percentage of students' combined answers is presented in Figure 1.

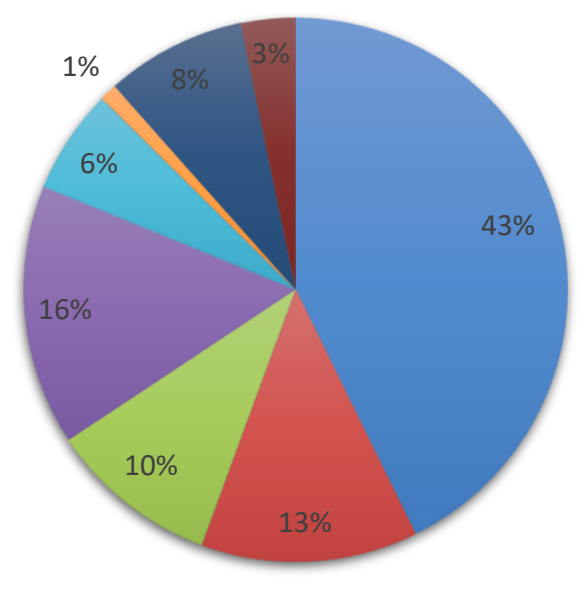

- Conceptual Understanding - Type 1 Misconception

- Type 2 Misconception

-Type 3 Misconception

- Type 1 of lack understanding

- Type 2 of lack understanding

-Type 3 of lack understanding

Guess

Figure 1. Percentage of Three Tier Multiple Choice Test Answer Results

Analysis of the answers of students is done by grouping answers based on categories of understanding of concepts that have been determined. Based on Figure 1. $43 \%$ of students already understand the concept, $39 \%$ of students experience misconceptions, $15 \%$ of students lack understanding of the concept and $3 \%$ of the students just guess. As many as $39 \%$ of students still experience misconceptions where students write the answers correctly, but the reasons stated are not right and are sure of the answers given. This is different from the results of a study conducted by Latisma et al. (2015) of $27.36 \%$ of students experiencing misconceptions. This can be caused by several factors, one of which is the inadequate time to study exact subjects especially chemistry subjects.
Students in the category of conceptual understanding in colloidal material reached $43 \%$, while based on research conducted by Latisma et al. (2015) the average student who understood the concept with various learning styles was $22.92 \%$. This can be due to differences in the application of the learning model and approach used. Based on students' responses to the application of the learning model used, it was found that the response from students was quite good, namely $77.5 \%$. This shows that the application of the learning model used can help students in understanding concepts in colloidal material.

The percentage of students' analysis of the answers of all questions based on classical concept understanding indicators can be seen in Figure 2. 


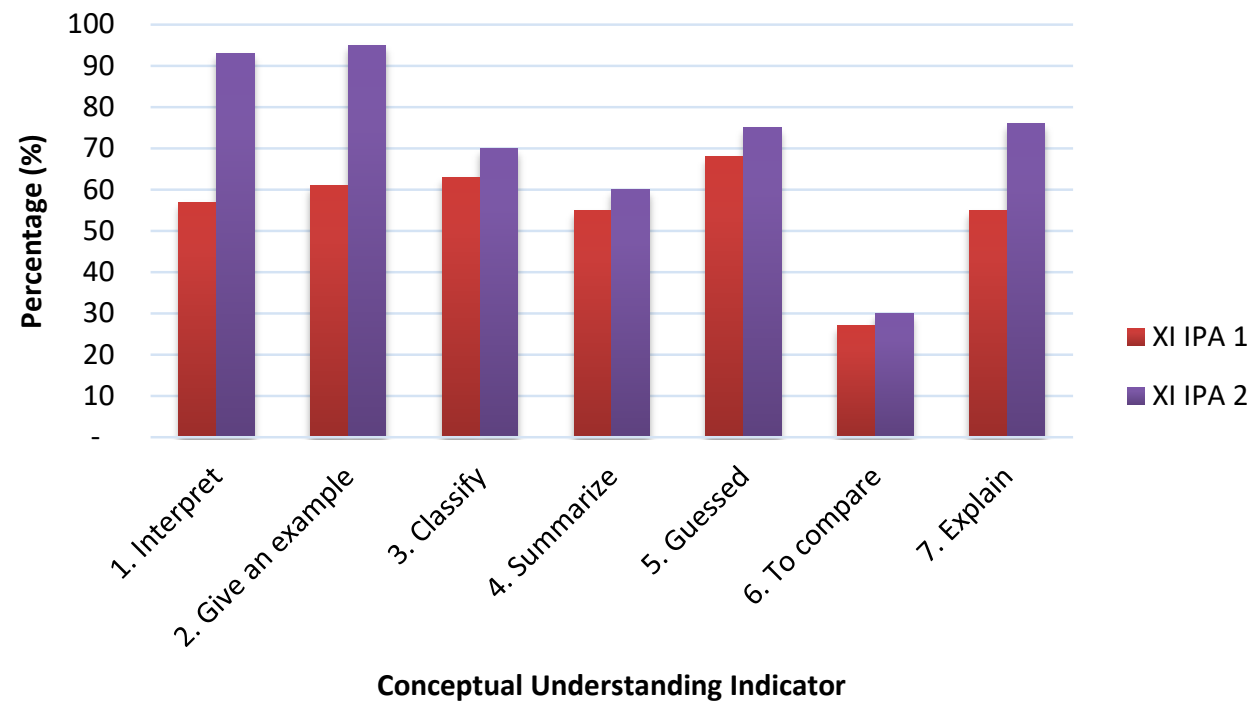

Figure 2. Percentage of Student Answers Based on Concept Understanding Indicators

Based on Figure 2, it can be seen that the highest average percentage is found in the indicator giving examples with an average percentage of $95 \%$. It is marked as many as 38 students can answer correctly on questions with indicators giving examples contained in questions number 10 and number 17. The lowest percentage is in the indicators comparing with an average value of $27 \%$. This is different from the results of research conducted by Salawati et al. (2016) which mentions the lowest percentage found in students' answers with indicators mentioning differences in mixture based on physical appearance, stability and manner of separation. This can be caused by the ability of students to analyze a question is still weak, other than that students are not accustomed to solving problems related to a concept.

The results of students' answers from the test questions about colloids are grouped on the sub-material of the colloidal system, the nature of colloids, the manufacture of colloids and the application of colloids in everyday life. From the 20 numbers of concept understanding test questions, there are 9 numbers with colloidal system sub-material, 3 numbers of colloidal properties namely numbers 7,8 and 9 . While the making and application of colloids are 6 and 2 numbers respectively. The percentage of students' answers classically based on colloidal sub material is presented in Figure 3.

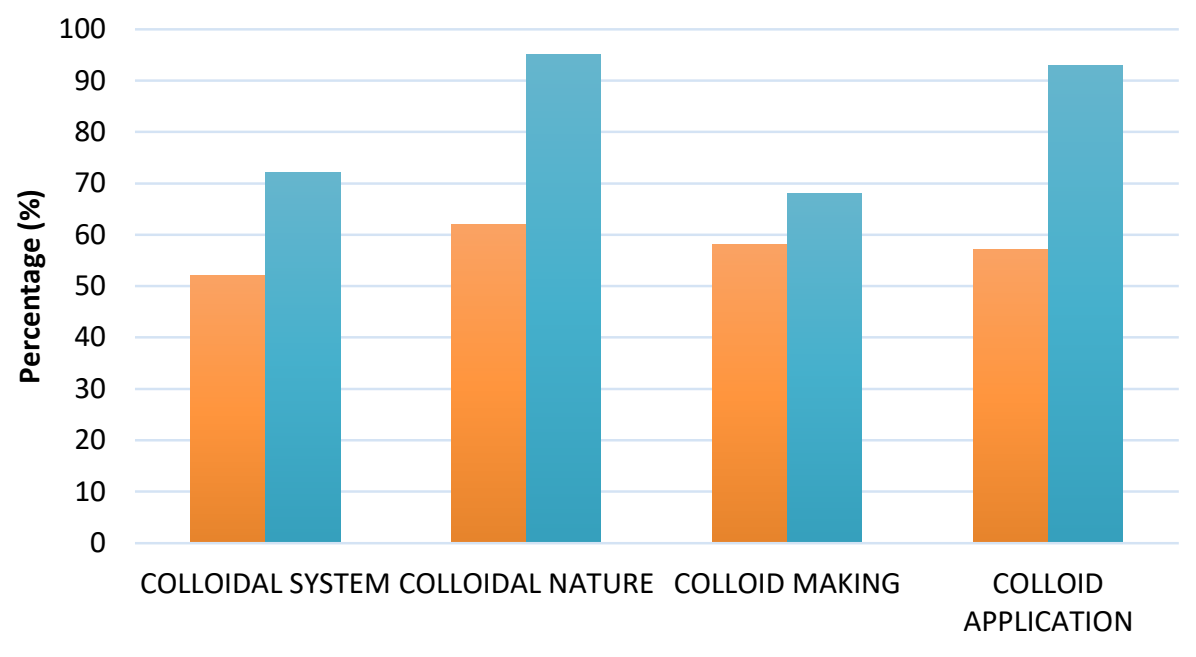

XI IPA $1 \square$ XI IPA 2

Figure 3. Percentage of students' answers on the colloidal sub material 
Based on Figure 3, the average percentage of correct answers of students is found in the submaterial colloidal nature, while the average percentage of incorrect answers is found in the sub-material of the colloidal system. In the colloidal system sub-material, as many as $59 \%$ of students in class XI IPA1 were able to answer correctly, this could be due to some students not being able to distinguish several types of colloids. While in class XI IPA 2 students answered correctly more than $80 \%$ or 16 students out of 20 students in the class. Whereas in the colloidal nature sub-material, the average percentage of answers from the two classes reached $78 \%$, class XI IPA 2 had an average better than class XI IPA 1 in this sub-material.

Based on these figures, the average percentage of correct answers in the colloidal submaterial and colloidal application in daily life are $60 \%$ and $70 \%$, respectively. The questions about making colloids are found in numbers $10,11,13,14,15$ and 16 . The questions in numbers 14 and 16 are the questions with the least correct answers. Students belong to the category of most misconceptions in question number 14, namely with indicators comparing the process of making colloids from several types of colloids. In class XI IPA 1 belongs to the category of lack of understanding for the answers to these questions. This can be caused by the ability of students to analyze a problem is still in the weak category due to lack of practice in solving problems with the type of analyzing.

In the colloidal application sub-material in daily life, students in class XI IPA 2 are able to answer questions correctly or are in the concept of understanding category as much as $93 \%$, while class XI IPA 1 only reaches $57 \%$ in the same category. The application of colloids in everyday life can be understood by students quite well because several different types of colloids have been found in everyday life such as milk, coconut milk, dust, smoke, clouds and others. But some students have not been able to explain the dispersed phase and the dispersing medium in each type of colloid precisely. Some students are still not right in distinguishing the dispersed phase and the dispersing medium in a colloid.

The lowest percentage in colloidal sub material is found in the colloidal system. This can be caused by several things, one of which is the lack of interest in reading by students. In addition, some students find it difficult to distinguish between several types of colloids. for example the difference between liquid aerosols with liquid soles or with emulsions. Colloidal material submaterial also has the lowest percentage. This is because in this sub-material, students have not been able to distinguish the manufacture of colloids by condensation and dispersion.

Data analysis of students' understanding of the concept as a whole, it can be said that there are still many students who are only able to explain concrete data but have not been able to analyze or have been unable to answer the question "Why". From interviews with several students, it is known that there are still quite a lot of students who learn to use rote learning methods, not understanding, so when students are asked why the answer is wrong, they answer "forget". For example, for question number 5, students are given a food ingredient in daily life about the types of colloids and their components, as many as $73.8 \%$ of students can answer correctly (conceptual understanding) and $21.42 \%$ of students experience misconceptions while there are $4.78 \%$ of students who answered correctly by guessing. This is in accordance with what was said by Pratiwi et al. (2015) that there is a relationship between the ability of memory with students' learning achievement on colloidal material. However this is different from the research conducted by Latisma et al. (2015) which shows different results where for sub-material types of colloids are in the category of partial understanding or misconception.

Analysis of students' answers in the highest misconception category was found in questions number 9 and 13. In questions number 9 and 13 students were asked to analyze questions about the nature of the colloids associated in everyday life. In question number $9,42.86 \%$ of students experienced misconceptions, $23.8 \%$ understood concepts and $28.57 \%$ lacked understanding of concepts and $4.76 \%$ guessed. Explanation from the teacher is still very much needed by students, for example students cannot remember the concept of the nature of colloids and their relationship in daily life because students only read the material without being given an 
explanation by the teacher. Another example is some students only remember the types of colloids but have not been able to determine the dispersed phase and dispersing medium of a colloidal sample. A mistake made by the teacher who considers that the colloidal system material is more memorized material, so that by assigning students to read, students will be able to understand colloidal material.

Misconceptions when giving preconceptions can be avoided by paying attention to alternative conceptions that might arise in students (Redhana et al., 2017). Students can reach deep understanding of concepts if they are able to relate the observed macroscopic changes with rearrangements that occur at the submicroscopic level at the right chemical equation at the symbolic level (Chandrasegaran et al., 2009).

The Problem Based Learning model makes learning more meaningful in accordance with research conducted by Dewi et al. (2013) that Problem Based Learning can improve social interaction and learning achievement in colloidal system material. The results of the study using crossword puzzles on colloidal material with the results of students' responses to the crossword media give positive responses and increase learning outcomes (Sulfia \& Habibati, 2017).

The results showed a positive response to the process of learning problem based learning with joyful learning approach with a crossword puzzle of $77.5 \%$. The existence of an unattractive response can be caused by the time of the implementation of learning at the last hour of learning, so that the enthusiasm of students is less than optimal.

\section{CONCLUSION}

Based on the above research it can be concluded that the concept of understanding students' understanding of colloidal material after the application of the problem based learning model with joyful learning approach shows that $43 \%$ of students in the conceptual understanding category, $39 \%$ of students experience misconceptions and $15 \%$ of students in the category of lack of understanding and $3 \%$ of students guessed answers. The highest percentage of students correct answers contained in the indicator shows interpreting the data and giving examples of colloidal material. This shows that most of the students were able to interpret the data and set examples well. Problem-based learning with a joyful learning approach is enough to help students in understanding students' concepts. While the lowest percentage is found in indicators comparing and analyzing the application of colloids in daily life.

\section{REFERENCES}

Abanikannda, M. O. (2016). Influence Of ProblemBased Learning in Chemistry on Academic Achievement of High School Students in Osun State, Nigeria. International Journal of Education, Learning and Development, 4(3), 55-63.

Arslan, H. O., Cigdemogluc, C., \& Moseley, C. (2012). A Three-Tier Diagnostic Test to Assess PreService Teachers' Misconceptions about Global Warming, Greenhouse Effect, Ozone Layer Depletion, and Acid Rain. International Journal of Science Education, 34(11), 1667-1686.

Asmani \& Jamal, M. (2014). Tips Aplikasi PAIKEM. Yogyakarta: Diva Press.

Bilkisty, U. I., Budiasih, E., \& Widarti, H. R. (2013). Pengeruh Penerapan Model Pembelajaran Learning Cycle 5 Fase-TSTS pada Materi Koloid Terhadap Hasil Belajar Siswa Kelas XI IPA SMA Negeri 1 Bululawang. http://jurnalonline.um.ac.id/data/artikel/artikelCC8D65844C72 30075FCF367C9A03AD21.pdf.

Chandrasegaran, A. L., Treagust, D. F., \& Mocerino, M. (2011). Facilitating High School Students' Use of Multiple Representations to Describe and Explain Simple Chemical Reactions. The Journal of the Australian Science Teachers Association, 57(4), 13-20.

Dewi, S., Sumarni, \& Amirudin, A. (2016). Penerapan Model Pembelajaran Problem Based Learning untuk Meningkatkan Keaktifan dan Ketrampilan Sosial Siswa Kelas V SDN Tangkil 01 Wlingi. Jurnal Pendidikan: Teori, Penelitian dan Pengembangan, 1(3), 281-288.

Isnaniyah, S., Sukardjo, J., \& Yamtinah, S. (2015). Metode Pembelajaran Teams Games Tournament (TGT) berbantuan Demonstrasi dan Kreativitas Terhadap Prestasi Belajar Sisiwa pada Pokok Bahasan Koloid Kelas XI SMA N Sumpiuh Semester Genap Tahun Ajaran 2011/2012. Jurnal Pendidikan Kimia (JPK) , 4(3), 19-24. 
Latisma, D., Fitri, R. L., \& Dewata, E. (2015). Analisis Kecenderungan Pemahaman Konsep Siswa Ditinjau dari Gaya Belajar pada Materi Sistem Koloid di SMA Kerinci. Prosiding SEMIRATA 2015 bidang MIPA BKS-PTN Barat (pp. 523-532). Pontianak: Universitas Tanjungpura, Pontianak.

Mushbiroh, Q., Muntari, M., \& Idrus, S. (2018). Pengaruh Pembelajaran Joyful Learning dengan Media Kartu aksi Terhadap Hasil Belajar Kimia Materi Koloid pada Kelas XI MIA MAN 2 Model Mataram. Chemistry Education Practice, 1(1), 27-33.

Permatasari, A., Mulyani, B., \& Nurhayati, N. (2014). Efektivitas Penggunaan Model Pembelajaran Joyful Learning dengan Metode Pemberian Tugas Terhadap Prestasi Belajar Siswa pada Materi Koloid Siswa kelas XI IPA SMA Negeri 1 Simo Tahun Pelajaran 2012/2013. Jurnal Pendidikan Kimia (JPK), 3(1), 117-122.

Pratiwi, A. E., Martini, K. S., \& Ariani, S. R. (2013). Hubungan Antara Kemampuan Memori dan Prestasi Belajar Kimia pada Materi Koloid Kelas XI Semester II SMA Negeri 2 Pati Tahun Ajaran 2011/2012. Jurnal Pendidikan Kimia, 2(2), 117-124.

Redhana, I., Sudria, I., \& Hidayat, I. (2017). Identification of Chemistry Learning Problems Viewed From Conceptual Change Model. Jurnal Pendidikan IPA Indonesia, 6(2), 356-364.

Salawati, M., Harun, A., \& Hadi, L. (2016). Pengaruh Model Guided Discovery Terhadap
Pemahaman Konsep Siswapada Materi Koloid SMA. Jurnal Pendidikan dan Pembelajaran Katulistiwa, 5(8), 1-9.

Soesanto, H. (2017). Model Pembelajaran Inkuiri untuk Meningkatkan Pemahaman Konsep Siswa SMK pada topik Koloid. Papua: SEAMEO QITEP IN SCIENCE.

Sugiyono, P. D. (2016). Metode Penelitian Kuantitatif, Kualitatif dan R\&D. Bandung: CV. Alfabeta.

Sulfia, U. \& Habibati. (2017). Penerapan Media Teka Teki Silang pada Materi Koloid untuk Meningkatkan Hasil Belajar Peserta Didik. Jurnal IPA dan Pembelajaran IPA (JIPI) 1(1), 6-15.

Triastuti, R., Asikin, M., \& Wijayanti, K. (2014). Keefektifan Model CIRC berbasis Joyfull Learning terhadap Kemampuan Penalaran Matematis Siswa SMP. Unnes Journal of Mathematics Education, 132-137.

Wei, C. W., Hung, I. C., Lee, L., \& Chen, N. S. (2011). A Joyful Classroom Learning System with Robot Learning Companion for Children to Learn Mathematics Multiplication. TOJET: The Turkish Online Journal of Educational Technology 10(2), 11-23.

Yahya, S., Supardi, K. I., \& Masturi. (2017). Satesik (Sains, Teknologi \& Musik) untuk Meningkatkan Minat Belajar dan Pemahaman Konsep Sains. Journal of Innovative Science Education 6(1), 104-115. 